\title{
CZY CHRZEŚCIJANIN MUSI BYĆ KREACJONISTA MŁODEJ ZIEMI?
}

\section{Podstawowa typologia teorii początków}

Analizę stosunku Kościoła katolickiego do kreacjonizmu młodej Ziemi należy rozpocząć od krótkiej prezentacji stanowisk obecnych we współczenym sporze o pochodzenie gatunków. Taka ogólna „mapa światopoglądowa” pomoże nam zrozumieć, co stanowi przedmiot naszych rozważań, a co istotnie wykracza poza ramy niniejszego artykułu.

We współczesnej debacie na temat początków możemy wyróżnić cztery zasadcznie stanowiska. Możemy zaryzykować tezę, że wszystkie współczesne poglądy dają się sprowadzić do jednego z tych czterech. Są to: ewolucjonizm ateistyczny, ewolucjonizm teistyczny, kreacjonizm progresywny oraz kreacjonizm młodej Ziemi. Po szczegółowe omówienie tych stanowisk odsyłam do moich innych tekstów. ${ }^{1}$ Tutaj skupię się jedynie na czwartym stanowisku, gdyż ono właśnie stanowi temat naszych rozważań.

Kreacjonizm młodej Ziemi to pogląd stanowiący, że stworzenie świata dokonało się w ciągu sześciu dni rozumianych jako dni naturalne (sześć dób) oraz że wydarzenia stwórcze miały miejsce ok. 6 tys. lat temu. Odległość czasowa wydarzeń stwórczych (6 tys. lat) uzyskiwana jest przez kalkulację historii Ziemi na podstawie genealogii i historycznych przekazów biblijnych (ok. 4 tys. lat od Adama do Jezusa i ok. 2 tys. lat od Jezusa do dzisiaj). Natomiast sześć dni stworzenia bierze się wprost z pierwszego opisu stworzenia

1 Zob. M. C h a b e r e k, Kościół a ewolucja, Fronda, Warszawa 2012, s. 66-72; t e n ż e, Aquinas and Evolution, The Chartwell Press, 2017, s. 22-26. 
zawartego w rozdziale pierwszym Księgi Rodzaju. Oczywistą konsekwencją przyjęcia takiego poglądu jest to, że wiek świata nie różni się znacząco od wieku Ziemi, który z kolei nie jest dłuższy niż ok. 6 tys. lat. Jednocześnie kreacjonizm młodej Ziemi odrzuca teorię ewolucji (makroewolucji biologicznej) jako możliwe wyjaśnienie powstania gatunków. Powody są dwa. Po pierwsze, 6 tys. lat to o wiele za krótko, by jakiekolwiek znaczące wydarzenia ewolucyjne mogły nastąpić. Po drugie, Księga Rodzaju wyraźnie wskazuje na nadprzyrodzone pochodzenie gatunków, które są rozróżnione „według ich rodzajów” od samego początku istnienia, zatem nie mogą wywodzić się od wspólnego przodka na drodze naturalnego zrodzenia. Naturalnej ewolucji kreacjonizm młodej Ziemi przeciwstawia specjalne stworzenie.

Jak widzimy, kreacjonizm młodej Ziemi definiuje się w odpowiedziach na trzy osobne pytania: czas stwarzania świata, wiek świata, oraz stworzenie gatunków w przeciwieństwie do ich pochodzenia ewolucyjnego. Pozostałe trzy stanowiska również definiują się przez odpowiedź na te trzy pytania, tyle że ich odpowiedzi są inne. Różnice można przedstawić w postaci tabeli:

\begin{tabular}{|l|c|c|c|}
\hline & Czas stwarzania & Wiek świata & $\begin{array}{c}\text { Pochodzenie } \\
\text { gatunków }\end{array}$ \\
\hline $\begin{array}{l}\text { Ewolucjonizm } \\
\text { ateistyczny }\end{array}$ & $\begin{array}{c}\text { Swiat nieustannie for- } \\
\text { muje się sam zgodnie } \\
\text { z prawami natury }\end{array}$ & $\begin{array}{c}\text { Ok. 13,2 mld } \\
\text { lat }\end{array}$ & Ewolucja \\
\hline $\begin{array}{l}\text { Ewolucjonizm } \\
\text { teistyczny }\end{array}$ & $\begin{array}{c}\text { Creatio continua } \\
\text { świat jest nieustannie } \\
\text { stwarzany }\end{array}$ & $\begin{array}{c}\text { Ok. 13,2 mld } \\
\text { lat }\end{array}$ & Ewolucja \\
\hline $\begin{array}{l}\text { Kreacjonizm } \\
\text { progresywny }\end{array}$ & $\begin{array}{c}\text { Od początku świata do } \\
\text { stworzenia Adama (ok. } \\
13.2 \text { mld lat) }\end{array}$ & $\begin{array}{c}\text { Ok. 13,2 mld } \\
\text { lat }\end{array}$ & Stworzenie \\
\hline $\begin{array}{l}\text { Kreacjonizm } \\
\text { młodej Ziemi }\end{array}$ & $\begin{array}{c}\text { Sześć dni rozumianych } \\
\text { jako naturalne doby }\end{array}$ & Ok. 6 tys. lat & Stworzenie \\
\hline
\end{tabular}

Jak wynika z tabeli, jedynie kreacjonizm młodej Ziemi odrzuca powszechnie akceptowany w nauce wiek świata szacowany obecnie na ponad 13 mld lat. Pozostałe trzy stanowiska przyjmują, że naukowe 
datowanie wieku (czy to wieku Ziemi, czy wieku świata) jest poparte wieloma niezależnymi metodami, a zatem jest wiarygodne. Ponadto w kreacjonizmie progresywnym, podobnie jak w ewolucjonizmie teistycznym, uznaje się, że długi wiek świata (ang. deep time) nie zaprzecza przesłaniu biblijnemu i dlatego nie stanowi wyzwania dla wiary chrześcijańskiej. Należy jednak zauważyć, że oba rodzaje kreacjonizmu odrzucają możliwość ewolucjnego powstania gatunków, natomiast rozwiązanie to przyjmują oba rodzaje ewolucjonizmu. Zatem oś sporu między koncepcjami ewolucjonistycznymi i kreacjonistycznymi tkwi w zagadnieniu powstania różnorodności biologicznej świata: Czy gatunki wyewoluowały od wspólnego przodka na zasadzie naturalnego zrodzenia, czy zostały stworzone osobno na mocy nadprzyrodzonego działania Bożego? Te dwa poglądy nie mogą zostać sprowadzone do jednego. Nie da się logicznie spójnie twierdzić, że gatunki zostały i stworzone i wyewoluowały. Wynika to $\mathrm{z}$ natury pojęć - stworzenie to działanie nadprzyrodzone i bezpośrednie (bez udziału przyczyn wtórnych), natomiast ewolucja to proces naturalny, taki, który może być poddany badaniom naukowym i nie wymaga żadnego nadprzyrodzonego, tzn. przekraczającego prawa natury, działania Bożego. Ewolucja logicznie wyklucza stworzenie, ponieważ nie może ten sam akt być jednocześnie naturalny i nadprzyrodzony, bezpośredni i zapośredniczony. Zatem, jeżeli w teistycznym ewolucjonizmie mówi się o stworzeniu, to rozumie się je jedynie jako pierwsze wyłonienie świata z niczego (moment często utożsamiany z Wielkim Wybuchem) lub w sposób metaforyczny, jako pewną ogólną ideę, że wszystko ostatecznie pochodzi od Boga. Natomiast w kreacjonizmie stworzenie rozumie się zgodnie $\mathrm{z}$ tradycyjnym rozumieniem chrześcijańskim, w którym Bóg nie tylko stworzył świat z niczego w pierwszym akcie, ale również kształtował ten świat w sposób nadprzyrodzony w czasie, który Księga Rodzaju określa mianem sześciu dni. ${ }^{2}$

2 Takie klasyczne rozumienie stworzenia prezentuje np. św. To m a s z z A kwinu, S.Th. I,66-74. 
Z zaprezentowanej tutaj typologii wynika, że kreacjonizm młodej Ziemi jako jedyny odrzuca długie istnienie świata i przyjmuje rozumienie dnia stworzenia w opisie z Księgi Rodzaju jako naturalną dobę. Wielu kreacjonistów młodej Ziemi uważa, że takie stanowisko jest jedynym dopuszczalnym w ramach prawowierności chrześcijańskiej. Warto też dodać, że kreacjoniści młodej Ziemi znajdują się nie tylko wśród protestantów (tzw. fundamentalistów biblijnych), ale także wśród wyznawców prawosławia i katolików, zarówno świeckich jak i duchownych, teologów, jak też naukowców. ${ }^{3}$ Zjawisko kreacjonizmu młodej Ziemi występuje więc ponad podziałami wyznaniowymi i kulturowymi. Nie ma na nie wpływu wykształcenie (wielu kreacjonistów młodej Ziemi to ludzie z wyższym wykształceniem) ani kraj pochodzenia. W istocie kreacjonistów młodej Ziemi można znaleźć również wśród Żydów i muzułmanów. Należy więc zapytać, czy stanowisko to jest jedynym poglądem zgodnym z wiarą chrześcijańską (jak uważają sami kreacjoniści młodej Ziemi)? Czy Kościół katolicki zdefiniował swoją odpowiedź w tej kwestii? A także, jakie są źródła przekonania, o tym, że należy odrzucić długi wiek świata? Najpierw odpowiemy na ostatnie z postawionych pytań.

\section{Źródła współczesnej koncepcji kreacjonizmu młodej Ziemi}

Aż do drugiej połowy XVIII w., czyli dlugo po przewrocie kopernikańskim i wielu innych odkryciach nowożytnej nauki, nie było podejrzenia, że wiek Ziemi (i świata) może różnić się od tego, co sugerują genealogie biblijne. Studiując Stary Testament, można w przybliżeniu obliczyć, kiedy nastąpiło stworzenie świata. Takie próby nie były obce Ojcom Kościoła i pisarzom chrześcijańskim. Jednak rozwój metody naukowej zapoczątkowany w XVI w. oraz ekspansja wiedzy przyrodniczej przyczyniły się do coraz większego

3 Do znanych współczesnych protestanckich kreacjonistów młodej Ziemi należą Duane Gish, Kent Hovind, Ken Ham i wielu innych. Natomiast wśród katolików należy wymienić osoby takie jak J.W.G. Johnson, Hugh Owen, Maciej Giertych, Wolfgang Smith. 
zainteresowania historią naturalną świata. W miarę jak kolejni wybitni badacze odkrywali nowe prawdy dotyczące świata - takiego, jaki jawi się obecnie - ich uwaga kierowała się również ku badaniu przeszłości. Wielcy naukowcy, tacy jak Kepler i Newton, nie stronili od Biblii jako podstawy do określania wieku świata. ${ }^{4}$ Nie byli w tym zamiarze odosobnieni. Podobne zadanie stawiali sobie liczni teologowie, zwłaszcza protestanccy. Chyba najbardziej wpływowy okazał się anglikański biskup Jame Ussher (1581-1656), według którego Ziemia została stworzona 22 października 4004 r. przed Chr., w sobotę, o szóstej wieczorem. ${ }^{5}$ Również w pierwszym wydaniu encyklopedii Britannica z 1771 r. można było przeczytać, że świat został stworzony w roku zero, czyli 4007 lat przed Chr. ${ }^{6}$ W 1830 r. William Hales opublikował dzieło, w którym zamieścił listę stu dwudziestu autory tetów nauki i teologii wraz z ich szacunkami wieku wszechświata. Wyniki ich obliczeń wahały się między 6984 a 3616 lat przed Chr. ${ }^{7}$ Jak widać, posługiwanie się Biblią w celu ustalenia wieku wszechświata we wczesnej nowożytności (XVI-XIX w.) było powszechną praktyką, nie tylko wśród teologów, ale i przyrodników.

Jednak pod koniec XVIII w. wiele się zmieniło. Poczynając od szkockiego geologa Jamesa Huttona (1726-1797), w przyrodoznawstwie zaczęło krążyć alternatywne datowanie Ziemi. Nowa metoda była oparta nie na Piśmie Świętym, lecz na obserwacji przyrody najpierwo osadów morskich (jak w przypadku Huttona), później

4 Na przykład Jan Kepler, obliczył, że świat został stworzony w 3993 r. przed Chr. Do podobnych wniosków doszli Jan Heweliusz, Izaak Newton, Lord Kelvin i wielu reprezentantów nowożytnej nauki.

5 Por. I. U. A r m a c h a n o, Annales Veteris Testamenti a prima mundi origine deducti, w: The Whole Works of the Most Rev. James Ussher, D.D., t. 8, Londini 1650, s. 7.

6 Zob. Astronomy, w: Encyclopcedia Britannica, t. 1, Edinburgh 1771, s. 493.

7 W 1830 r. dr William Hales opublikował książkę Chronologia i geografia. Można w niej znaleźć listę 120 autorytetów nauki i teologii, którzy obliczali wiek świata. Ich wyniki mają rozpiętość od 6984 do 3616 r. przed Chr. Zob. W. H a le s, A New Analysis of Chronology and Geography, t. 1, C.J.G. \& F. Rivington, London 1830, s. 211-214. 
warstw kopalnych, a w końcu kosmicznego promieniowania tła i rozpadu pierwiastków promieniotwórczych (np. datowanie radiowęglowe). Już pierwsze obserwacje naukowe wykazały, że formacje geologiczne na Ziemi muszą być dużo starsze niż sugerowane przez teksty biblijne 6 tys. lat. Pod koniec XVIII w. mówiono o setkach tysięcy lat, w połowie XIX w. (w czasach Darwina) wiek świata szacowano już na $100 \mathrm{mln}$ lat. Liczba ta w początkach XX w. urosła do kilkuset milionów, gdy ostatecznie została zasąpiona innym rzędem wielkości, mianowicie miliaradmi lat. Twórca teorii ekspansji wszechświata, Edwin Hubble (1889-1953), oszacował wiek świata na ok. 8 mld lat. Później jego obliczenia jeszcze uściślono i obecnie w nauce powszechnie przyjmuje się, że świat ma ok. 13-14 mld lat a Ziemia ok. 4,6 mld. To oczywiście dużo więcej niż kilka tysięcy. Zatem wiek Ziemi (i świata) ustalony przez nowożytną naukę różni się znacznie od tego, jaki badacze ustalili na podstawie Pisma Świętego. Jednak, jak się wydaje, wiek świata, podobnie jak kontrowersja geocentryzm-heliocentryzm, nie wpływa w istotny sposób na chrześcijańskie rozumienie prawd wiary. Nasuwa się więc pytanie: Dlaczego niektórzy chrześcijanie postanowili odrzucić naukowe datowanie wszechświata? W istocie kreacjoniści młodej Ziemi poszli jeszcze dalej - nie tylko przeciwstawili Biblię danym naukowym, ale także podjęli zadanie naukowego obalenia obliczeń współczesnej nauki. To podejście określa się obecnie mianem $\mathrm{k} \mathrm{r} \mathrm{e} \mathrm{a} \mathrm{c} \mathrm{j} \mathrm{o} \mathrm{n} \mathrm{i} \mathrm{z} \mathrm{m} \mathrm{u}$ n a u k owe go.

I rzeczywiście, istnieje zupełnie inny, pozanaukowy powód, dla którego część chrześcijan (zwłaszcza protestantów) odrzuciła dowody na długi wiek świata. Otóż wraz z rozpowszechnieniem się teorii ewolucji (druga połowa XIX w.) zaatakowane zostały biblijne prawdy dotyczące stworzenia, takie jak uformowanie gatunków mocą Boga i stworzenie człowieka z prochu ziemi. Okazało sie zatem, że środowiska naukowe - przynajmniej ta ich część, która popierała teorię makroewolucji biologicznej-używały nauki w celu obalenia prawdy o początkach świata tak jak przedstawia je Księga Rodzaju. Najpopulrniejszą chrześcijańską odpowiedź na tę nową teorię naukową stanowił teistyczny ew olucjonizm, czyli pogląd, jakoby 
Bóg nie stworzył gatunków swoją bezpośrednią i nadprzyrodzoną mocą, lecz posłużył się procesem naturalnej ewolucji jako wtórną przyczyną stworzenia. Nieuniknioną konsekwencją przyjęcia teistycznej ewolucji było uznanie zwierzęcego pochodzenia człowieka.

W katolicyzmie teistyczny ewolucjonizm był kwestionowany jeszcze przez sto lat (do ok. połowy XX w.), jednak ostatecznie pogląd ten zdominował teologię. ${ }^{8}$ Jednak w protestantyzmie teistyczny ewolucjonizm wywołał dużo mocniejszy sprzeciw. Było to spowodowane przede wszystkim zasadą sola Scriptura, na której opierała się teologia protestancka. Jest jasne, że teoria makroewolucji biologicznej wyklucza historyczne i realistyczne rozumienie Księgi Rodzaju. Zanegowanie znaczenia tekstu biblijnego znacznie ułatwiła metoda krytyczno-historyczna, która w tym samym czasie rozpowszechniła się w chrześcijaństwie. Zatem, z jednej strony, dekonstrukcja Pisma Świętego, a z drugiej bezkompromisowe narzucenie teorii makroewolucji biologicznej przez świat nauki niejako zmusiły teologów do wycofania się z klasycznego chrześcijańskiego rozumienia stworzenia. W tym kontekście część chrześcijan - tych, którzy nie zgadzali się na porzucenie Księgi Rodzaju - doszło do wniosku, że cały problem ewolucjonizmu i liberalnej egzegezy ma swoje źródło w zakwestionowaniu historii biblijnej, której znaczącym elementem są genealogie i opis stworzenia. Jedynym sposobem obrony dawnych pozycji było zanegowanie teorii makroewolucji biologicznej. To z kolei najłatwiej było zrobić przez podważenie długiego wieku świata. Jeżeli bowiem stworzenie dokonało się w sześć naturalnych dni jedynie ok. 6 tys. lat temu, to ewolucja - tak jak rozumiał ją Darwin i większość naukowców - jest niemożliwa. Obalenie wielu milionów i miliardów lat historii świata stało się kluczem do obrony prawdziwości Biblii. Tym właśnie należy tłumaczyć żywotność kreacjonizmu młodej Ziemi.

Kreacjoniści młodoziemscy mieli dobre intencje. Jednak pomieszali dwa rodzaje pytań: Pytanie o wiek świata oraz pytanie o pochodzenie świata (gatunków i człowieka). Niestety, notoryczne

8 O tym jak do tego doszło zob. M. C h a b e r e k, Kościół a ewolucja, s. 211-216. 
podważanie danych naukowych dotyczących wieku świata pozbawiło wiarygodności rzetelną krytykę teorii ewolucji prezentowaną przez kreacjonistów młodej Ziemi. Widać zatem jak radykalne przyjęcie zasady sola Scriptura negatywnie wpłynęło nie tylko na rozumienie samego tekstu Pisma Świętego, ale także osłabiło argumentację przeciwko naukowemu materializmowi promowanemu $\mathrm{w}$ formie teorii Darwina.

\section{Tradycyjna teologia katolicka a kwestia wieku wszechświata}

Zarówno katoliccy jak i protestanccy zwolennicy kreacjonizmu młodej Ziemi twierdzą, że całe chrześcijaństwo od starożytności do Darwina utrzymywało literalne rozumienie opisu z Księgi Rodzaju, krótki wiek świata (ok. 4 tys. lat przed Chr.) oraz stworzenie w ciągu sześciu naturalnych dni. ${ }^{9}$ Takie twierdzenie ma większe znaczenie dla katolików, ponieważ w katolicyzmie uznaje się tradycję Kościoła za normę wiary. Musimy zatem zapytać, czy rzeczywiście tradycja Kościoła jednoznacznie opowiada się za kreacjonizmem młodej Ziemi? Ponownie należy przypomnieć rozróżnienie trzech pytań wiek świata, czas stworzenia i sposób stworzenia. Tutaj nie będziemy zajmować się pytaniem o sposób stworzenia, ponieważ ono nie dotyczy kwestii wieku świata. Jest to pytanie o to, ja k różne byty zostały powołane do istnienia, a nie $\mathrm{k}$ i e d y to się stało.

Zasadniczo wszystkie teologiczne argumenty zwolenników kreacjonizmu młodej Ziemi sprowadzają się do dwóch: I. Ojcowie Kościoła

9 Jedna z najbardziej wpływowych organizacji protestanckich promujących kreacjonizm młodej Ziemi. na swojej stronie internetowej publikuje dość ogólnikowy artykuł na poparcie tej tezy. Zob. https://answersingenesis.org/christianity/church/ the-early-church-on-creation/ (dostęp: 13 VI 2017). Wśród katolików obronę tej tezy podjął w monumentalnym opracowaniu ksiądz V. P. W a r k u l w i z, The Doctrines of Genesis 1-11. A Compendium and Defense of Traditional Catholic Theology on Origins, IUniverse Inc., Lincoln 2007. Podobnie Hugh Owen, katolicki badacz, założyciel Kolbe Center, dowodzi, że tradycyjna teologia katolicka zawsze popierała młodą Ziemię. Zob. http://kolbecenter.org/the-traditional-catholic-doctrine-of-creation/ (dostęp: 13 VI 2017). 
powszechnie mówili o sześciu dniach stworzenia; II. Czwarty Sobór Laterański zdefiniował doktrynę o jednoczesnym stworzeniu wszystkiego. Należy osobno odpowiedzieć teraz na te dwa argumenty.

Ad I. Jest prawdą, że Ojcowie Kościoła i późniejsi święci Doktorzy powszechnie mówili o tym, że stworzenie dokonało się w ciągu sześciu dni. Tradycyjna teologia popierała literalne i historyczne rozumienie Księgi Rodzaju. Jednak nie jest pewne, czy dzień - hebrajski wyraz yom w opisie stworzenia - rozumieli jako naturalny dzień (12 godzin), czy jakąś epokę lub po prostu czas, który Biblia określa mianem dnia. Warto zauważyć, że rozumienie dnia jako epoki nie sprzeciwia się literalnemu czytaniu tekstu - po prostu pod literą dnia kryje się określenie odcinka czasu, którego dokładnej długości nie znamy i nie potrafimy odczytać z Biblii. Jest wiele argumentów za rozumieniem dnia jako czasu innego niż naturalna doba. Na przykład Pismo Święte mówi, że Bóg odpoczął siódmego dnia, co znaczy, że stworzenie definitywnie się zakończyło i stan ten trwa do dzisiaj. Można z tego wnioskować, że siódmy dzień trwa do dzisiaj. W Drugim Liście św. Pawła, właśnie w kontekście stworzenia świata i oczekiwania na paruzję, czytamy, że, ,jeden dzień u Pana jest jak tysiąc lat, a tysiąc lat jak jeden dzień" (2P 3,8). Podobnie w Psalmie 90 czytamy, że „tysiąc lat w oczach Bożych jest jak wczorajszy dzień, który minął” (Ps 90,4). Nie ma wątpliwości, że Pismo Święte dość często mówi o dniu jako pewnym okresie i nie ma podstaw, aby wykluczać taką interpretację w odniesieniu do opisu stworzenia. Nie ma także podstaw, by uznać, że Ojcowie Kościoła wykluczali takie rozumienie dnia.

Nieco inaczej niż większość Ojców rozumiał opis stworzenia św. Augustyn. Według niego nie można mówić o sześciu dniach jako naturalnych dobach, ponieważ Słońce zostało stworzone dopiero czwartego dnia. Zatem nie byłoby nawet jak odmierzyć pierwszych trzech dni. Warto zwrócić uwagę, że (wbrew przekonaniom teistycznych ewolucjonistów) Augustyn, tak samo jak inni Ojcowie, poszukiwał literalnego (nie metaforycznego) rozumienia opisu stworzenia. Augustyn nieustannie podkreślał, że jego komentarze do Księgi Rodzaju są komentarzami literalnymi. To właśnie wierność literze 
tekstu kazała mu zanegować następstwo sześciu dni. W konsekwencji uznał, że Bóg stworzył wszystko w jednym momencie, a sześć dni odpowiada sześciostopniowemu poznaniu stworzenia, które Bóg przekazał aniołom. ${ }^{10}$ Jednocześnie Augustyn mocno bronił wieku świata, opierając się na genealogiach biblijnych. To skłoniło go do uznania, że świat istniał jedynie przez ok. 4 tys. lat przed Chr. Co ciekawe, Augustyn zdawał sobie sprawę z tego, że nawet świeckie kroniki niektórych ludów sięgały dalej w przeszłość. Jednak nie wpadł na pomysł, że być może genealogie biblijne nie są kompletne. Zamiast tego uznał, że poganie zmyślili swoją historię, aby obalić prawdziwość Pisma Świętego. Mamy więc u niego dość nietypowe rozwiązanie: sześci dni z opisu stworzenia to jeden moment czasowy, ale czas istnienia świata to nie więcej niż kilka tysięcy lat. Wiele wieków później, św. Tomasz będzie usiłował wykazać, że interpretacja Augustyna nie różni się znacząco od klasycznej interpretacji, jaką znajdujemy u św. Ambrożego i większości świętych. ${ }^{11} \mathrm{Z}$ koncepcji Augustyna wynikają dwa wnioski: po pierwsze, przynajmniej jeden Ojciec Kościoła wyraźnie odrzucał interpretację dnia stworzenia jako naturalnej doby. Po drugie, ten sam Ojciec uważał, że przedstawia interpretację literalną, w takim sensie, że trzyma się litery tekstu, choć nie jest to interpretacja historyczna, to znaczy idąca za chronologią pierwszego opisu ( $\mathrm{Rdz} 1)$.

Ad II. Interpretację Augustyna dodatkowo wspierał fragment Księgi Syracha, w którym czytamy: „Ten, który żyje na wieki, stworzył wszystko jednocześnie” (Syr 18,1a: „qui vivit in aeternum creavit omnia simul"). Jednak łaciński przekład, z którego korzystał Augustyn, niezbyt dobrze odzwierciedla greckie słowa panta koine użyte w Septuagincie. O ile tekst Wulgaty sugeruje jednoczesne stworzenie wszystkiego, o tyle grecki tekst mówi o tym, że Bóg stworzył „wszystko bez wyjątku” (tak ma też Biblia Tysiąclecia). Zatem tekst Mądrości Syracha nie stanowi dobrego poparcia dla koncepcji jednorazowego stworzenia. Zwolennicy kreacjonizmu młodej Ziemi.

10 Zob. A u gu s t y n, De Civitate Dei, Liber XI, cap. 7. PL, t. 41, c. 322-323.

1 Zob. Tom as z z A kwinu, S.Th. I,74,2, co. 
powołują się jeszcze na orzeczenie Czwartego Soboru Laterańskiego: „Od początku czasu [Bóg] stworzył jednocześnie (simul) z niczego oba porządki stworzeń, duchowe i cielesne, tj. anielskie i ziemskie, a następnie (deinde) istotę ludzką". ${ }^{12}$ Po pierwsze, zauważmy, że wykorzystywanie tego fragmentu przeciwko długiej historii stworzenia przez kreacjonistów młodej Ziemi jest nielogiczne, ponieważ, gdyby uznać, że fragment ten popiera Augustyńską koncepcję stworzenia symultanicznego, to sprzeciwiałby się on miliardom lat tak samo mocno jak sześciu naturalnym dniom. Przecież sześć dni stanowi następstwo czasowe tak samo jak miliardy lat. Jednak w istocie orzeczenie soborowe nie wyklucza następstwa czasowego i dlatego jest zgodne zarówno z koncepcją starej jak i młodej Ziemi. Dlaczego tak jest, wyjaśnił już w XIII w. św. Tomasz, który również spotkał się z zarzutem, że nie ma następstwa czasowego w stworzeniu. W jego przypadku zarzut ten popierano wspomnianym już cytatem z Księgi Syracha $(18,1)$. Tomasz odpowiada jednak, że stworzenie „wszystkiego jednocześnie na początku" odnosi się do pierwotnej materii z ogólnymi formami, co nie przeszkadza, by Bóg wzbogacał tę materię nowymi formami dalej w czasie określanym mianem sześciu dni. Sam Tomasz mówi o dziele rozróżniania (opus distintionis) i dziele ozdabiania świata (opus ornatus) ${ }^{13} \mathrm{~W}$ orzeczeniu soborowym jest to bardzo jasne, ponieważ o jednoczesnym stworzeniu mówi się tam tylko w sposób ogólny, jako o bytach widzialnych i niewidzialnych, natomiast gdy mowa o jednej specyficznej naturze, jaką jest natura ludzka, pojawia się słowo ,następnie” (deinde). To oznacza, że człowiek powstał później, już po pierwszysm stworzeniu (prima creatio). Zatem orzeczenie soborowe nie tylko nie wyklucza, ale wręcz popiera następstwo czasowe w dziele stworzenia. To zaś nijak się ma do koncepcji młodej Ziemi.

12 Czwarty Sobór Laterański (1215), DS 800; por. Konstytucja dogmatyczna I Soboru Watykańskiego Dei Filius, I, DS 3002.

13 Zob. Tom as z z A k w in u, S.Th. I,74,2 ad 4; por. te n ż e, Super Sent. Lib. 2 d. 12 q.1 a. 2 , ad 1. 


\section{Zagadnienia religijne a zagadnienia naukowe}

Do tej pory wyjaśniliśmy, że ani Pismo Święte, ani tradycja teolgiczna Kościoła nie zmusza chrześcijan do wiary w kreacjonizm młodej Ziemi. Zwolennicy młodej Ziemi próbują negować naukowe datowanie świata, gdyż uważają, że w ten sposób bronią historyczną prawdę Pisma Świętego przed unieważnieniem ze strony zarówno liberalnej egzegezy, jak i ateistycznej nauki. Jednak podejście to wynika z niezrozumienia podziału kompetencji między teologią i naukami szczegółowymi. Przy okazji warto zaznaczyć, że takie samo niezrozumienie widać u teistycznych ewolucjonistów, którzy uważają, że w imię tzw. postępu nauki (lub „odkryć naukowych”) należy zrezygnować z wiary w osobne stworzenie gatunków lub stworzenie ludzkiego ciała z prochu ziemi.

Aby zrozumieć różnice kompetencji nauki ${ }^{14}$ i teologii, należy wpierw wyjaśnić, że część naszej wiedzy o świecie pochodzi z badań naukowych (nauk szczegółowych), ale inna część tej wiedzy wymyka się metodzie naukowej. Dobry przykład stanowią cuda. Cuda zachodzą w świecie materialnym, ale nie mają wyjaśnienia przyrodniczego, w istocie cud definiuje się właśnie jako zdarzenie, którego nie da się wyjaśnić naukowo (definicja negatywna). Cuda dają się jednak wyjaśnić w świetle teologii - wiemy, że kiedy cud zachodzi, Bóg działa mocą nadprzyrodzoną, która wykracza poza moc naturalnie obecną w przyrodzie. I podobnie ma się sprawa $\mathrm{z}$ innymi zagadnieniami dotyczącymi świata. Na przykład przeznaczenie świata według nauki to śmierć termiczna, powrót kosmosu do chaosu, czyli rozpad wszelkiej organizacji do stanu doskonałej entropii (brak jakiejkolwiek zorganizowanej struktury). Oczywiście, taki „świat” nie rokuje dobrze dla gatunku ludzkiego, który musiałby zginąć długo przed śmiercią termiczną świata. Jednak teologia daje inne wyjaśnienie, bardziej optymistyczne, gdyż mówi o zmartwychwstaniu

14 Słowa „nauka” konsekwentnie używamy w jego nowożytnym rozumieniu, jako określenie nauk przyrodniczych. W tym sensie teologia nie jest nauką, choć jest jedną (najważniejszą!) z dyscyplin poznawczych. 
i cudownym przekształceniu świata w królestwo niebieskie. Która z dyscyplin ma rację - nauka czy teologia? To czas pokaże.

Ale podobnie jak nauki nie mogą wyjaśnić przeznaczenia świata, tak też nie mogą wyjaśnić jego pochodzenia. I to nie tylko w tym najbardziej ogólnym sensie stworzenia z niczego, ale również w sensie pochodzenia specyficznych form tego świata, takich jak gatunki istot ożywionych, a zwłaszcza człowieka. Pytania o początki nie są pytaniami naukowymi (w sensie nauk przyrodniczych). Przekraczają kompetencje przyrodoznawstwa. Mieszczą się jednak w ramach teologii, gdyż Bóg objawił człowiekowi właśnie te prawdy, których nie mógłby on odkryć na drodze badań naturalnych. I dlatego sposób powstania świata wyjaśnia teologia czerpiąca swe przesłanki z Pisma Świętego. Natomiast wiek świata nie jest pytaniem o początki. Jest pytaniem o stan współczesny - jak stara jest Ziemia dzisiaj? Ile lat ma wszechświat? I dlatego wiek świata leży w kompetencji nauki. Tak jak biologia może określić wiek drzewa, paleontologia może określić, od kiedy istnieją krokodyle na Ziemi, tak też fizyka i astronomia mogą określić wiek świata. Pytanie o wiek jest pytaniem naukowym. I dlatego odpowiedzi nie należy szukać w Biblii. Pan Bóg napisał w księdze stworzenia to, czego nie można wyczytać w księdze zbawienia, jaką jest Pismo Święte. Z tego też powodu odkrycia naukowe dotyczące wieku i budowy świata nie wpływają w żaden sposób na rozumienie prawd wiary. Nauki przyrodnicze oferują coraz nowsze teorie wyjaśniające działanie świata, a prawdy wiary pozostają niezmienione. Również datowanie świata, jak wykazaliśmy wyżej, zmieniało się na przestrzeni czasu. I chociaż są dobre powody, by uznać, że obecne datowanie jest ostateczne, nie ma teoretycznych przeszkód, aby nauka odkryła w przyszłości, że świat jest dużo starszy lub dużo młodszy, niż to się dzisiaj przyjmuje. To nie będzie miało wpływu na nasze rozumienie stworzenia. Kreacjoniści młodej Ziemi usiłują więc bronić prawdy nieistotnej z punktu widzenia wiary. W ten sposób stają często przeciwko nauce, kreując wrażenie, że nauka i religia są w nieuchronnym konflikcie. Właściwe rozróżnienie kompetencji obu dyscyplin jest warunkiem 
skutecznej obrony wiary w stworzenie w kulturze zdominowanej przez ewolucjonizm.

\section{Orzeczenie Magisterium Kościoła}

Postawiliśmy pytanie, czy katolik musi być kreacjonistą młodej Ziemi. Katolik, podobnie jak każdy człowiek, nie może być głuchy na głos nauki. Jeżeli wierzymy, że obie księgi - natury i Pisma Świętego - mają jedno Boskie źródło, to nie mogą one zawierać sprzecznych odpowiedzi. Jednak wyjaśnienia nauk przyrodniczych nie mają tak wysokiej pewności jak dogmaty wiary czy zasady filozofii. Zatem, aby uznać prawdę głoszoną przez naukę o długim wieku wszechświata, trzeba usunąć wszelkie domniemane przeszkody teologiczne. Kreacjoniści młodej Ziemi wskazują wiele takich przeszkód, ale sprowadzają się one do dwóch omówionych wyżej. Żadna z nich nie stanowi autentycznej przeszkody do przyjęcia długiego wieku świata. Dodatkowo katolicy dysponują jednym mało znanym orzeczeniem doktrynalnym Kościoła, które w zasadzie rozwiązuje problem kreacjonizmu młodej Ziemi. Jest to odpowiedź Papieskiej Komisji Biblijnej z 1909 r. Dokument zawiera odpowiedzi na osiem pytań dotyczących historycznego i literalnego rozumienia rozdziałów 1-3 Księgi Rodzaju. Siódma odpowiedź stwierdza, że katolicki intepretator nie jest zmuszony do szukania ściśle naukowego sensu w każdym wyrażeniu, natomiast ósma odpowiedź stwierdza, że wyraz „dzień” (hebr. yom) użyty w opisie stworzenia może być rozumiany w jego ścisłym sensie jako dzień naturalny, albo w sensie jakiegoś innego odcinka czasu; wolna dyskusja w tej materii jest dopuszczalna. ${ }^{15}$ Jest więc jasne, że Kościół pozostawia otwartą kwestię czasu trwania dnia z opisu stworzenia. To zaś oznacza, że katolik może, ale nie musi, być kreacjonistą młodej Ziemi. To orzeczenie ma pełną wartość doktrynalną i stanowi oficjalne stanowisko Kościoła

15 Enchiridion Biblicum. Documenta Ecclesiastica Sacram Scripturam Spectantia. Auctoritate Pontificiae Comissionis de Re Biblica edita, Apud Libreriam Vaticanam, Romae 1927, s. 99 (EB 335-339). 
aż do dziś. ${ }^{16}$ Zastanawiający jest fakt, że kreacjoniści młodej Ziemi, którzy często odwołują się do soborów i dokumentów Magisterium, zupełnie ignorują to publiczne orzecznie o charakterze doktrynalnym. Dodatkowo warto zaznaczyć, że - niezależnie od dyskusji naukowej na temat wieku świata - Kościół, kierując się świętą tradycją, wydał tak dojrzałe orzeczenie już w początku XX w. Wynika $z$ tego, że prawdziwe odkrycia naukowe nie przeczą wierze. Mogą jej natomiast przeczyć teorie tworzone w nauce, ale przekraczające kompetencje nauki.

Z dotychczasowych analiz wynika, że kreacjonizm młodej Ziemi jest stanowiskiem dość nowym w chrześcijaństwie, które ukształtowało się w odpowiedzi na podważanie autorytetu Pisma Świętego czy to w liberalnej egzegezie, czy też w świecie nauki. Istotę tego stanowiska stanowi odrzucenie zarówno ewolucyjnej interpretacji początków świata jak i naukowego datowania wieku świata. Jak wykazaliśmy, długi wiek świata nie musi zaprzeczać Pismu Świętemu, a tym bardziej nie zaprzecza wierze katolickiej. Jest to koncepcja naukowa, która nie ingeruje istotnie w teologię. Można więc wnioskować, że stanowisko młodoziemskie łączy w sobie dwie idee klasyczną chrześcijańską naukę o stworzeniu oraz przednaukowe rozumienie historii świata. O ile pierwsza $\mathrm{z}$ tych idei należy do wiary i jako taka domaga się teologicznej obrony, o tyle druga stanowi przekroczenie granic teologii i jako taka stanowi deprecjację nauki w imię źle rozumianej religii. Niestety, stawianie tych dwóch problemów na równym poziomie istotności prowadzi do pomieszania dyskursów teologicznego i naukowego. Kreacjonizm młodej Ziemi wymaga więc głębszego przemyślenia. Kościół, z doktrynalnego punktu widzenia, nie zabrania tego stanowiska. Jednocześnie kreacjoniści młodej Ziemi

16 O aktualności tych orzeczeń, a także o nieudanych próbach unieważnienia ich przez teologów zob. M. C h a b e r e k, Kościół a ewolucja, s. 183-192. 
nie mogą twierdzić, że ich stanowisko jest jedynym dopuszczalnym w ramach ortodoksji chrześcijańskiej.

ks. Michat CHABEREK

Słowa kluczowe: kreacjonizm, ewolucjonizm, stworzenie, Księga Rodzaju, nauka, religia

Keywords: creationism, evolution debate, creation, The Book of Genesis, science, religion

\section{Whether or not a Christian has to be a Young Earth creationist Summary}

This paper answers the question of whether or not a Christian has to be a Young Earth creationist. The article opens with the typology of the current positions in the creation-evolution debate. Basing itself on this typology, it presents Young Earth creationism as one of four positions, the only one that denies the concept of "deep time". Next, the paper presents the genesis of Young Earth creationism in Western thought. In the third part there is a brief response to the argument of the proponents of a Young Earth that early Christianity supported the young age of the universe. In the following part it is explained that Young Earth creationism confuses the scientific with the theological statements. At the end, a document of the Catholic Church is presented which explains that Catholics can understand the "day" in the creation account as either a natural day or any other period of time. This makes room for other positions within Catholic orthodoxy apart from that of a Young Earth 